\title{
Propionicimonas paludicola gen. nov., sp. nov., a novel facultatively anaerobic, Gram-positive, propionate-producing bacterium isolated from plant residue in irrigated rice-field soil
}

\author{
Hiroshi Akasaka, ${ }^{1}$ Atsuko Ueki, ${ }^{1}$ Satoshi Hanada, ${ }^{2}$ Yoichi Kamagata ${ }^{2}$ \\ and Katsuji Ueki ${ }^{1}$ \\ ${ }^{1}$ Faculty of Agriculture, Yamagata University, Wakaba-machi 1-23, Tsuruoka 997-8555, Japan \\ ${ }^{2}$ Institute for Biological Resources and Functions, National Institute of Advanced Industrial \\ Science and Technology (AIST), Tsukuba Central 6, Higashi 1-1-1, Tsukuba 305-8566, Japan
}

Correspondence

Atsuko Ueki

uatsuko@tds1.tr.yamagata-u.ac.jp

\section{INTRODUCTION}

Rice serves as the principal food for nearly half of the world's population; about $90 \%$ of the total area of rice fields in the world is found in Asia. Rice fields are differentiated into four ecosystems: irrigated, rain-fed,

Published online ahead of print on 13 June 2003 as DOI 10.1099/ ijs.0.02764-0.

Abbreviations: DAP, diaminopimelic acid; RS plot, rice-straw plot; TEM, transmission electron microscopy.

The GenBank/EMBL/DDBJ accession numbers for the 16S rDNA sequences of strains $\mathrm{Wd}^{\top}$ and $\mathrm{Wf}$ are AB078858 and AB078859, respectively.

Micrographs of strains $\mathrm{Wd}^{\top}$ and $\mathrm{Wf}$ are available as supplementary material in IJSEM Online. deepwater and upland fields. The former three soils (about $90 \%$ of the global area) (Wassmann et al., 2000b) become anoxic after flooding and the methanogenic microbial community develops with active degradation of organic matter (Takai, 1970; Seiler et al., 1984; Glissmann \& Conrad, 2000). Thus, the rice-field ecosystem is considered to be one of the major sources of global atmospheric methane (Khalil, 2000). Many studies have investigated anaerobic microbial communities in anoxic rice-field soil (Janssen et al., 1997; Großkopf et al., 1998; Henckel et al., 1999; Hengstmann et al., 1999) and novel anaerobic micro-organisms have been isolated (Rajagopal et al., 1988; Asakawa et al., 1995; Chin et al., 1998, 1999; Rosencrantz et al., 1999; Wind et al., 1999; Satoh et al., 2002).

Japan is located in the rice-producing district of Asia and rice cultivation using irrigated fields has been practiced for 
a long time. Rice straw and remaining plant residue, such as rice stubble and roots, are ploughed into the soil at the beginning of the growing season to act as organic fertilizers. Such additions often result in an increase in methane emission rates from the fields (Yagi \& Minami, 1990; Watanabe et al., 1995; Wassman et al., 2000a). In a previous study, we reported the enumeration and isolation of anaerobic fermentative bacteria from rice-plant residue ploughed into the soil of a Japanese rice field (Akasaka et al., 2003). Of the 47 bacterial isolates that were analysed by means of $16 \mathrm{~S}$ rDNA sequence, five strains in the Actinobacteria commonly produced propionate from glucose. This group was phylogenetically distinct and was tentatively named the 'propionate-producing Actinobacteria group'. We have investigated the phenotypic characteristics of representative strains of this group and from the results obtained, we propose a novel genus and species, Propionicimonas paludicola gen. nov., sp. nov., for these isolates.

\section{METHODS}

Bacterial strains. Strains W1, Wd ${ }^{\mathrm{T}}\left(=\mathrm{JCM} 11933^{\mathrm{T}}=\mathrm{DSM} 15597^{\mathrm{T}}\right)$, Wf (=JCM $11934=$ DSM 15598), K2 and K5 in the 'propionateproducing Actinobacteria group' were isolated previously from plant-residue samples collected from the rice straw (RS) plot in the Shonai Branch of the Yamagata Agricultural Experimental Station (Fujishima-machi, Yamagata, Japan) during the rice-growing season (Akasaka et al., 2003). Rice straw had been applied annually to this plot for more than 20 years. Cultivation practices for rice plants and characteristics of the soil were described previously (Ueki et al., 1999, 2000; Kaku et al., 2000; Hattori et al., 2001, 2002). Strains were isolated by selecting individual colonies after counting anaerobic bacteria on plant residue collected from the soil. Methods used have been described previously (Hungate, 1966; Holdeman et al., 1977; Akasaka et al., 2003). Strains $\mathrm{W} 1, \mathrm{Wd}^{\mathrm{T}}$ and $\mathrm{Wf}$ were isolated from rice-straw samples, whereas strains $\mathrm{K} 2$ and $\mathrm{K} 5$ were derived from rice stubble and roots. Strains W1, K2 and K5 were isolated in May, during the flooding period of the field, and the other strains were isolated in August, during the intermittent irrigation period (Akasaka et al., 2003).

Culture conditions. Strains were cultivated anaerobically at $30{ }^{\circ} \mathrm{C}$ by using peptone/yeast extract (PY) medium as basal medium with oxygen-free, $95 \% \mathrm{~N}_{2} / 5 \% \mathrm{CO}_{2}$ mixed gas as the headspace, as described previously (Akasaka et al., 2003). PY medium supplemented with $\left(1^{-1}\right) 0.25 \mathrm{~g}$ each of glucose, cellobiose, maltose and soluble starch, as well as $50 \mathrm{ml}$ plant residue extract (RE) and $15 \mathrm{~g}$ agar (Difco), was designated PY4SR agar and used for maintenance of the strains in agar slants. Plant residue collected from the RS plot during the flooding period was autoclaved $\left(120^{\circ} \mathrm{C}\right.$ for $\left.30 \mathrm{~min}\right)$ with a fivefold amount (wet-weight basis) of deionized $\mathrm{H}_{2} \mathrm{O}$ and the supernatant obtained after centrifugation was used as RE for the provision of growth factors. PY liquid medium supplemented with 10 g glucose $1^{-1}$ (PYG medium) was usually used for cultivation of the cells. For PY liquid medium, cyanocobalamin (cobalamin) (vitamin $\mathrm{B}_{12}$; Kanto Chemical) was added at $50 \mu \mathrm{g}^{-1}$ as a growth factor as described below, unless stated otherwise. Media were adjusted to $\mathrm{pH} 7 \cdot 3$ with $1 \mathrm{M} \mathrm{NaOH}$. For estimation of optimal growth conditions, strains were cultivated at different temperatures $\left(10-50{ }^{\circ} \mathrm{C}\right)$, $\mathrm{pH}$ values $(4 \cdot 6-7 \cdot 5$ in $\mathrm{PYG}$ medium) and $\mathrm{NaCl}$ concentrations $(0-5.0 \%$ in PYG medium). Growth in liquid medium was monitored by changes in $\mathrm{OD}_{660}$.
Morphological characteristics. Morphology of cells was observed by Gram-staining, phase-contrast microscopy and transmission electron microscopy (TEM). For TEM, a centrifuged cell pellet was fixed with $5 \%(\mathrm{v} / \mathrm{v})$ glutaraldehyde and $1 \%(\mathrm{v} / \mathrm{v})$ osmium tetroxide. Ultrathin sections of the sample, embedded in epoxy resin (Kushida, 1980), were prepared with a Reichert ultramicrotome. Samples were stained with uranyl acetate and lead citrate and examined with a Hitachi H-7000 transmission electron microscope.

Physiological and biochemical characterization. Growth of strains under aerobic conditions was examined by plate culture on nutrient agar (Nissui Pharmacy) and PY4SR agar. Spore formation was assessed after Gram-staining, as well as under phase-contrast microscopy and by subsequent growth in PYG medium of cells exposed to $80^{\circ} \mathrm{C}$ for $10 \mathrm{~min}$. Oxidase, catalase and nitrate-reducing activities were determined according to methods described previously (Satoh et al., 2002; Akasaka et al., 2003). Utilization of carbon sources was tested in PY liquid medium with each substrate added at $10 \mathrm{~g} \mathrm{l}^{-1}$ (for mono-, di-, tri- and polysaccharides and sugar alcohols) or $30 \mathrm{mM}$ (for alcohols and organic acids). Fermentation products were analysed as described previously (Ueki et al., 1986; Akasaka et al., 2003). Glucose concentrations in the media were measured with a D-glucose kit (Boehringer Mannheim) according to the manufacturer's protocol. All phenotypic characterizations, including the following chemotaxonomic analyses, were carried out in duplicate.

Quinone, fatty acid and cell-wall analyses. Quinones were extracted from freeze-dried cells with chloroform/methanol $(2: 1$, $\mathrm{v} / \mathrm{v}$ ) and $\mathrm{n}$-hexane. Extracts were purified by using Sep-Pak Plus (Waters) and analysed by reverse-phase HPLC for identification (Tamaoka et al., 1983). Whole-cell fatty acids were converted to methyl esters by treatment with anhydrous methanolic HCl (Ueki \& Suto, 1979; Komagata \& Suzuki, 1987). Methyl esters were extracted with n-hexane and analysed by using a GC-mass spectrometer (M7200A GC/3DQMS; Hitachi) equipped with a DB-5ms capillary column coated with $5 \%$ phenylmethylpolysiloxane at a thickness of $250 \mathrm{~nm}$ (Hanada et al., 2002). The presence of diaminopimelic acid (DAP) isomers in the cell-wall peptidoglycan was determined by TLC (no. 5716; Merck) after hydrolysis with $6 \mathrm{M} \mathrm{HCl}$ at $100{ }^{\circ} \mathrm{C}$ for 18 h (Komagata \& Suzuki, 1987).

DNA base composition. Genomic DNA was extracted according to a method described previously (Kamagata \& Mikami, 1991). Extracted DNA was digested with P1 nuclease by using a Yamasa GC kit (Yamasa Shoyu) and its $\mathrm{G}+\mathrm{C}$ content was measured by HPLC (model LC-6A system; Shimadzu) equipped with a CLC-ODS column $(6 \times 150 \mathrm{~mm}$; Shimadzu $)$.

165 rDNA sequence and phylogenetic analysis. 16S rDNA of strains was extracted according to a method described previously (Akasaka et al., 2003) and amplified by PCR. PCR-amplified $16 \mathrm{~S}$ rDNA was sequenced by using a Thermo Sequenase Primer Cycle Sequencing kit (Amersham Biosciences) and a model 4000L DNA sequencer (LI-COR). Multiple alignments of isolates' sequences with reference sequences in GenBank were performed with the BLAST program (Altschul et al., 1997). A phylogenetic tree was constructed with the neighbour-joining method (Saitou \& Nei, 1987) by using the CLUSTAL W program (Thompson et al., 1994). All gaps and unidentified base positions in the alignments were excluded before assemblages.

\section{RESULTS AND DISCUSSION}

\section{Cobalamin requirement of the isolates}

The five isolates have 16S rDNA similarity values of $98 \cdot 0$ $99 \cdot 7 \%$ to each other and all are facultatively anaerobic, 
Gram-positive, irregular rods with a similar morphology (Akasaka et al., 2003). However, the five isolates could be divided into two groups according to their growth in PYG medium. Four isolates (W1, $\mathrm{Wd}^{\mathrm{T}}, \mathrm{K} 2$ and $\left.\mathrm{K} 5\right)$ showed extremely slow growth rates without addition of any growth factors, whereas strain Wf grew well. For slowgrowing isolates, $16 \mathrm{~S}$ rDNA similarities among three strains $\left(\mathrm{W} 1, \mathrm{Wd}^{\mathrm{T}}\right.$ and $\mathrm{K} 5$ ) were $99 \cdot 4-99 \cdot 7 \%$, whereas those with strain K2 were lower $(98 \cdot 0-98 \cdot 3 \%)$.

By screening possible growth factors, addition of cobalamin to PYG medium markedly stimulated the growth of the four slow-growing strains. Table 1 shows the effects of cobalamin addition on growth (final $\mathrm{OD}_{660}$ ) and fermentation end products. In PYG medium without added cobalamin, all isolates except strain Wf formed small amounts of products, with lactate as the predominant one. In the presence of added cobalamin, production of propionate was stimulated together with acetate, whilst lactate changed to a minor product. Although strain Wf produced large amounts of fatty acids in PYG medium with no growth factor addition, cobalamin also stimulated its growth and production of propionate, again with a concomitant suppression of lactate production. All isolates produced $\mathrm{CO}_{2}$ as well as fatty acids, but hydrogen production was not observed.

To further investigate the effects of cobalamin on slowgrowing isolates, strain $\mathrm{Wd}^{\mathrm{T}}$ was cultivated in the presence of different amounts of cobalamin in PYG medium and time-courses for growth and end products were examined (data not shown). Without added cobalamin, strain $\mathrm{Wd}^{\mathrm{T}}$ grew very slowly, showing an arithmetic increase in OD. With addition of $1 \mu \mathrm{g}$ cobalamin $\mathrm{l}^{-1}$, its growth improved markedly and lactate was produced as the predominant fatty acid from the onset of fermentation. With $20 \mu \mathrm{g}$ cobalamin $1^{-1}$, propionate accumulated rapidly to a much higher concentration than that of any other product, whilst lactate production was suppressed significantly compared to that in the presence of $1 \mu \mathrm{g}$ cobalamin $1^{-1}$. The other three slow-growing strains (W1, K2 and K5) showed similar changes in the time-course of growth, depending on cobalamin concentrations.

Strains $\mathrm{Wd}^{\mathrm{T}}$ and $\mathrm{Wf}$ were selected and characterized in more detail. In later experiments, both isolates were cultured in media that contained an excess amount of cobalamin $\left(50 \mu \mathrm{g} \mathrm{l}^{-1}\right)$.

\section{Colony and cell morphologies}

Strains $\mathrm{Wd}^{\mathrm{T}}$ and Wf grew anaerobically on PY4SR agar and produced white colonies of $2-3 \mathrm{~mm}$ diameter after 2-3 days incubation. Cells were Gram-positive, pleomorphic, often slightly curved rods, $0 \cdot 4-0 \cdot 5 \mu \mathrm{m}$ in diameter and $1 \cdot 4-2 \cdot 2 \mu \mathrm{m}$ in length. Irregular V- or crescent-shaped cell arrangements were observed frequently (see Supplementary Figs a and c, available as supplementary material in IJSEM Online). Cells were non-motile under phasecontrast microscopy. TEM showed that cells had a cell-wall structure typical of Gram-positive bacteria (Supplementary Figs $b$ and $d$ ). Electron-translucent regions in the cells revealed the presence of intracellular storage compounds. Spore formation was not observed and cells treated at $80^{\circ} \mathrm{C}$ for 10 min did not grow.

\section{Physiological and biochemical characteristics}

Strains $\mathrm{Wd}^{\mathrm{T}}$ and Wf had very similar physiological and biochemical characteristics. Both grew weakly in air on both PY4SR and nutrient agar, but much better growth was observed under anaerobic conditions. Both utilized arabinose, xylose, fructose, galactose, glucose, mannose,

Table 1. Effects of addition of cyanocobalamin on growth and fermentation products of isolates in the propionate-producing group

All values were determined after 5 days incubation. -, Without cyanocobalamin added; +, with cyanocobalamin added; ND, not detected.

\begin{tabular}{|c|c|c|c|c|c|c|c|}
\hline \multirow[t]{2}{*}{ Strain } & \multirow[t]{2}{*}{ Cyanocobalamin ${ }^{*}$} & \multirow[t]{2}{*}{$\mathrm{OD}_{660}$} & \multirow[t]{2}{*}{$\mathrm{pH}$} & \multicolumn{4}{|c|}{ Fatty acids produced $\left(\mathrm{mmol} \mathrm{l}^{-1}\right)$} \\
\hline & & & & Acetate & Propionate & Lactate & Succinate \\
\hline \multirow[t]{2}{*}{ W1 } & - & $0 \cdot 28$ & $6 \cdot 22$ & 0.54 & $0 \cdot 80$ & $2 \cdot 29$ & $0 \cdot 11$ \\
\hline & + & $2 \cdot 21$ & $4 \cdot 60$ & $8 \cdot 12$ & $17 \cdot 5$ & $0 \cdot 49$ & ND \\
\hline \multirow[t]{2}{*}{$\mathrm{Wd}^{\mathrm{T}}$} & - & $0 \cdot 71$ & $5 \cdot 70$ & $2 \cdot 46$ & $0 \cdot 59$ & $4 \cdot 26$ & $2 \cdot 45$ \\
\hline & + & $2 \cdot 04$ & $4 \cdot 42$ & $8 \cdot 06$ & $17 \cdot 7$ & $3 \cdot 21$ & $0 \cdot 89$ \\
\hline \multirow[t]{2}{*}{ K2 } & - & $0 \cdot 53$ & $5 \cdot 67$ & $0 \cdot 92$ & $0 \cdot 74$ & $4 \cdot 27$ & $0 \cdot 32$ \\
\hline & + & $2 \cdot 11$ & $4 \cdot 52$ & $9 \cdot 47$ & $19 \cdot 0$ & ND & $\mathrm{ND}$ \\
\hline \multirow[t]{2}{*}{ K5 } & - & $0 \cdot 29$ & $6 \cdot 26$ & $1 \cdot 29$ & $0 \cdot 64$ & $3 \cdot 95$ & $0 \cdot 36$ \\
\hline & + & $1 \cdot 63$ & $4 \cdot 48$ & $6 \cdot 49$ & $20 \cdot 5$ & $1 \cdot 69$ & $0 \cdot 38$ \\
\hline \multirow[t]{2}{*}{ Wf } & - & $1 \cdot 87$ & $4 \cdot 35$ & $8 \cdot 12$ & $12 \cdot 3$ & $15 \cdot 2$ & $0 \cdot 53$ \\
\hline & + & $2 \cdot 40$ & $4 \cdot 34$ & $13 \cdot 8$ & $24 \cdot 7$ & $6 \cdot 01$ & $0 \cdot 27$ \\
\hline
\end{tabular}

${ }^{\star}$ Amounts of cyanocobalamin added: strains $\mathrm{Wd}^{\mathrm{T}}, \mathrm{K} 5$ and Wf, $10 \mu \mathrm{g} 1^{-1}$; strains $\mathrm{W} 1$ and $\mathrm{K} 2,50 \mu \mathrm{g} 1^{-1}$. 
cellobiose, maltose, sucrose, trehalose, glycerol and mannitol as carbon sources, whereas utilization of ribose and lactose was poor. Both strains grew on pyruvate and lactate; very weak growth was observed with malate, fumarate and succinate. Neither strain utilized fucose, rhamnose, sorbose, melibiose, melezitose, raffinose, cellulose, glycogen, soluble starch, xylan, adonitol, dulcitol, erythritol, inositol, sorbitol, ethanol, methanol or propanol as growth substrates. Other physiological characteristics of the two isolates are shown in Table 2.

\section{Chemotaxonomic characteristics}

Strains $\mathrm{Wd}^{\mathrm{T}}$ and $\mathrm{Wf}$ also had similar chemotaxonomic characteristics. The major cellular fatty acids in both were $\mathrm{C}_{13: 0}\left(11 \cdot 8 \%\right.$ for strain $\mathrm{Wd}^{\mathrm{T}}$ and $10.5 \%$ for strain $\left.\mathrm{Wf}\right)$, anteiso- $\mathrm{C}_{15: 0}\left(31.0\right.$ and $39.6 \%$, respectively) and $\mathrm{C}_{15: 0}$ $\left(40 \cdot 6\right.$ and $34 \cdot 1 \%$, respectively). Branched $\mathrm{C}_{14: 0}(5 \cdot 1$ and $5.5 \%$, respectively), $\mathrm{C}_{14: 0}(1.5$ and $2 \cdot 8 \%$, respectively), $\mathrm{C}_{16: 0}\left(1 \cdot 7\right.$ and $1 \cdot 4 \%$, respectively) and $\mathrm{C}_{17: 0}(4 \cdot 1$ and $1.5 \%$, respectively) were also detected as minor components. Major respiratory quinones of both strains were MK-9 $\left(\mathrm{H}_{4}\right)$ and MK-10 $\left(\mathrm{H}_{4}\right)$, with peak area ratios of 59:41 for strain $\mathrm{Wd}^{\mathrm{T}}$ and $77: 23$ for strain Wf. Other chemotaxonomic features are given in Table 2.

\section{Phylogenetic analysis based on 165 rDNA sequences}

A phylogenetic tree based on $16 \mathrm{~S}$ rDNA sequences was constructed (Fig. 1). Sequence similarity between the $16 \mathrm{~S} \mathrm{rDNA}$ of strains $\mathrm{Wd}^{\mathrm{T}}$ and Wf was $99 \cdot 1 \%$; both strains formed a cluster close to the genera Micropruina (Shintani et al., 2000), Microlunatus (Nakamura et al., 1995) and Friedmanniella (Schumann et al., 1997) in the Actinobacteria. The closest relative of both strains was Micropruina glycogenica (Shintani et al., 2000), with sequence similarities of 95.8 and $95.7 \%$, respectively. The closest relative to strain $\mathrm{Wd}^{\mathrm{T}}$ found in GenBank was environmental clone SJA-181 (Fig. 1), which was derived from an anaerobic microbial consortium in a trichlorobenzenetransforming bioreactor (von Wintzingerode et al., 1999), with $16 \mathrm{~S}$ rDNA sequence similarity of $98 \cdot 3 \%$.

The five strains used in this study were isolated from different plant residues at different sampling times and were thus considered to be part of a ubiquitous anaerobic bacterial group that occurs on plant residue in rice-field soil. Their population density was estimated to be at least of the order of $10^{8}-10^{9}$ c.f.u. (g dry wt plant residue) ${ }^{-1}$ (Akasaka et al., 2003).

Propionate is an important intermediate in methanogenic decomposition of organic matter in anoxic rice-field soils (Dolfing, 1988; Glissmann \& Conrad, 2000; Chin et al., 2001; Chin \& Janssen, 2002). The striking effects of cobalamin on growth and fermentation of the isolates suggest that survival of the group on plant residue at a rather high population density depends on the availability of cobalamin from the environment. A similar requirement for cobalamin has been reported in a ruminal propionateproducing bacterium, Prevotella ruminicola (Strobel, 1992).

Many propionate-producing bacteria produce propionate through conversion of succinyl-CoA to methylmalonyl$\mathrm{CoA}$, which is catalysed by a vitamin $\mathrm{B}_{12}$-dependent methylmalonyl-CoA isomerase (Roth et al., 1996). Stimulation of propionate production by added cobalamin suggests that this pathway is present in the isolates described here. Many other anaerobes, including methanogens and acetogens, synthesize cobalamin endogenously for their own use and several reactions, including reductive dehalogenation of chlorinated compounds, depend on cobalamin or vitamin $\mathrm{B}_{12}$ (Krone et al., 1989; Stupperich et al., 1990; White \& Zhou, 1993; Roth et al., 1996). Thus, cobalamin synthesized by various microbial groups may be released into the environment, where it may support the growth of cobalamin-requiring bacteria.

Phenotypic and phylogenetic characteristics of strains $\mathrm{Wd}^{\mathrm{T}}$ and Wf were almost the same, except for a requirement for cobalamin for their optimal growth. Micropruina glycogenica was the most closely related known species to both isolates, based on $16 \mathrm{~S} \mathrm{rDNA}$ sequence as described above, followed by Microlunatus phosphovorus (Nakamura et al., 1995) (similarity of $94 \cdot 7-95 \cdot 8 \%$ ) and Friedmanniella antarctica (Schumann et al., 1997) (similarity of 93.1\%), all in the family Propionibacteriaceae within the Actinobacteria (Garrity \& Holt, 2001) (Fig. 1). These data agree with the base compositions of their genomic DNA, which indicate that they both belong to the high-G + C Grampositive bacteria. However, many differences exist between the characteristics of these isolates and those of other closely related species (Table 2).

Their cellular morphologies show that the isolates are irregular rods, whereas other related species have spherical cells. The isolates are facultatively anaerobic and catalasenegative and grow well under anoxic conditions, whereas the other three species are strictly aerobic and catalasepositive. Both Micropruina glycogenica and Microlunatus phosphovorus have oxidase and nitrate-reducing activities, but the novel isolates do not. Furthermore, their cellular fatty acid composition profiles are different from those of their close relatives: major fatty acids of the isolates are $C_{13: 0}$, anteiso- $C_{15: 0}$ and $C_{15: 0}$, whereas those of the other three are iso- $\mathrm{C}_{14: 0}$, iso- $\mathrm{C}_{15: 0}$, anteiso- $\mathrm{C}_{15: 0}$, iso- $\mathrm{C}_{16: 0}$ or $\mathrm{C}_{16: 0}$. Fatty acids $\mathrm{C}_{13: 0}$ and $\mathrm{C}_{15: 0}$ are absent from, or only minor components in, other related species. Furthermore, most predominant fatty acids in their relatives, except for anteiso- $\mathrm{C}_{15: 0}$, are absent from, or only minor components in, the isolates described here. In addition to MK-9 $\left(\mathrm{H}_{4}\right)$, both isolates contain $\mathrm{MK}-10\left(\mathrm{H}_{4}\right)$ as a predominant menaquinone, whereas the other three species do not (Nakamura et al., 1995; Schumann et al., 1997; Maszenan et al., 1999; Shintani et al., 2000). Among their close relatives, only Micropruina glycogenica has meso-DAP in the peptidoglycan of the cell wall (Shintani et al., 2000). 
Table 2. Phenotypic characteristics of strains $\mathrm{Wd}^{\top}$ and $\mathrm{Wf}$ and related species in the Actinobacteria

Taxa: 1, Wd ${ }^{\mathrm{T}}$; 2, Wf; 3, Micropruina glycogenica [data from Shintani et al. (2000)]; 4, Microlunatus phosphovorus [data from Nakamura et al. (1995)]; 5, Friedmanniella antarctica [data from Schumann et al. (1997)]. All organisms are Gram-positive, non-motile and non-spore-forming. +, Positive; -, negative; ND, no data available.

\begin{tabular}{|c|c|c|c|c|c|}
\hline Characteristic & 1 & 2 & 3 & 4 & 5 \\
\hline Habitat & Plant residue in paddy soil & Plant residue in paddy soil & Activated sludge reactor & Activated sludge reactor & Antarctic sandstone \\
\hline Cell shape & Irregular rods & Irregular rods & Cocci & Cocci & Cocci \\
\hline Cell size $(\mu \mathrm{m})$ & $0 \cdot 4-0 \cdot 5 \times 1 \cdot 8-2 \cdot 0$ & $0 \cdot 4-0 \cdot 5 \times 1 \cdot 4-2 \cdot 2$ & $0 \cdot 5-2 \cdot 2$ & $0 \cdot 8-2 \cdot 0$ & $0 \cdot 5-2 \cdot 2$ \\
\hline Colour of colony & White & White & White & Cream & Orange \\
\hline \multicolumn{6}{|l|}{ Growth temperature $\left({ }^{\circ} \mathrm{C}\right)$ : } \\
\hline Optimum & 35 & 35 & 30 & $25-30$ & 22 \\
\hline Range & $10-40$ & $10-40$ & $20-30$ & $5-35$ & $9-25$ \\
\hline \multicolumn{6}{|l|}{ Growth pH: } \\
\hline Optimum & $6 \cdot 5$ & $6 \cdot 5$ & $7 \cdot 0$ & $7 \cdot 0$ & $6 \cdot 0-7 \cdot 2$ \\
\hline Range & $4 \cdot 5-7 \cdot 5$ & $4 \cdot 5-7 \cdot 5$ & $6 \cdot 0-8 \cdot 0$ & $5 \cdot 0-9 \cdot 0$ & $5 \cdot 1-8 \cdot 7$ \\
\hline $\begin{array}{l}\mathrm{NaCl} \text { concentration range } \\
\text { for growth }(\%)\end{array}$ & $0-2$ & $0-2$ & $0-3$ & $0-6$ & $0-2$ \\
\hline $\mathrm{O}_{2}$ requirement & Facultative anaerobe & Facultative anaerobe & Aerobe & Aerobe & Aerobe \\
\hline Cobalamin requirement & + & - & ND & ND & ND \\
\hline Oxidase & - & - & + & + & - \\
\hline Catalase & - & - & + & + & + \\
\hline Nitrate reduction & - & - & + & + & - \\
\hline Acid production from glucose & + & + & + & + & - \\
\hline DNA G + C content $(\mathrm{mol} \%)$ & $68 \cdot 7$ & $67 \cdot 4$ & $70 \cdot 5$ & $67 \cdot 9$ & $73 \cdot 0$ \\
\hline Major quinone & MK-9 $\left(\mathrm{H}_{4}\right)$, MK-10 $\left(\mathrm{H}_{4}\right)$ & MK-9 $\left(\mathrm{H}_{4}\right)$, MK-10 $\left(\mathrm{H}_{4}\right)$ & $\mathrm{MK}-9\left(\mathrm{H}_{4}\right)$ & MK- $9\left(\mathrm{H}_{4}\right)$ & MK-9 $\left(\mathrm{H}_{4}\right)$ \\
\hline Major cellular fatty acids & $\mathrm{C}_{13: 0}$, anteiso- $\mathrm{C}_{15: 0}, \mathrm{C}_{15: 0}$ & $\mathrm{C}_{13: 0}$, anteiso- $\mathrm{C}_{15: 0}, \mathrm{C}_{15: 0}$ & $\begin{array}{l}\text { iso- } \mathrm{C}_{14: 0,} \text { anteiso- } \mathrm{C}_{15: 0} \\
\text { iso- } \mathrm{C}_{16: 0}, \mathrm{C}_{16: 0}\end{array}$ & iso- $\mathrm{C}_{15: 0}$, anteiso- $\mathrm{C}_{15: 0}$, iso- $\mathrm{C}_{16: 0}$ & $\begin{array}{l}\text { iso- } \mathrm{C}_{15: 0} \\
\text { anteiso- } \mathrm{C}_{15: 0}\end{array}$ \\
\hline Peptidoglycan & meso-DAP & meso-DAP & meso-DAP & LL-DAP & LL-DAP \\
\hline
\end{tabular}




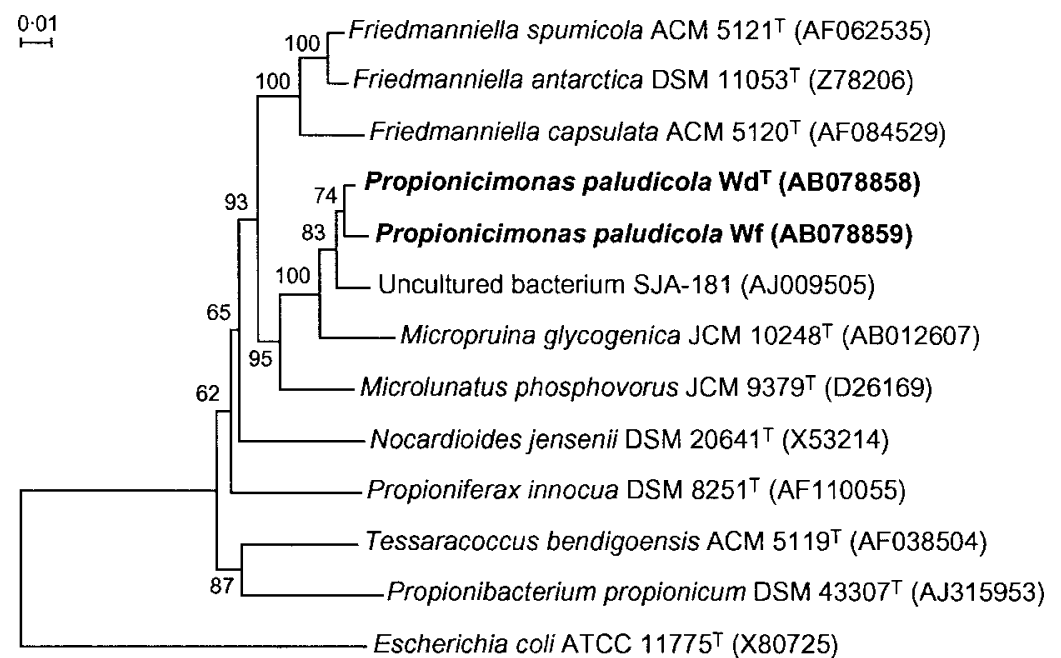

Fig. 1. Neighbour-joining tree showing the phylogenetic relationship of strains $\mathrm{Wd}^{\top}, \mathrm{Wf}$ and related species in the Actinobacteria, based on 16S rDNA sequences. Bootstrap values (\%) are shown for nodes with $>50 \%$ support in bootstrap analysis of 1000 replicates. The sequence of Escherichia coli, which belongs to the $\gamma$-Proteobacteria (Garrity \& Holt, 2001), was used as the outgroup. Bar, $1 \%$ estimated difference in nucleotide sequence position.
The isolates produce propionate in the presence of excess cobalamin and their fermentation patterns resemble those of Propionibacterium spp. (Cummins \& Johnson, 1986) and Propioniferax spp. (Yokota et al., 1994; Pitcher \& Collins, 1991) in the family Propionibacteriaceae (Garrity \& Holt, 2001). Despite this, they are only distantly related to Propionibacterium propionicum and Propioniferax innocua, based on $16 \mathrm{~S}$ rDNA sequence data (similarities of 91.592.0 and $90.0 \%$, respectively) (Fig. 1). Furthermore, both Propionibacterium propionicum and Propioniferax innocua contain LL-DAP in their cell-wall peptidoglycan and MK$9\left(\mathrm{H}_{4}\right)$ as the sole menaquinone (Maszenan et al., 1999). The predominant cellular fatty acids in Propioniferax innocua are also iso- $\mathrm{C}_{15: 0}$ and anteiso- $\mathrm{C}_{15: 0}$ (Schumann et al., 1997).

On the basis of both the phylogenetic and phenotypic characteristics described above, we conclude that $\mathrm{Wd}^{\mathrm{T}}$ and Wf should be assigned to the same species within a novel genus, Propionicimonas gen. nov., with Propionicimonas paludicola sp. nov. as the type species.

\section{Description of Propionicimonas gen. nov.}

Propionicimonas (Pro.pi.on.i.ci.mo'nas. N.L. n. acidum propionicum propionic acid; Gr. fem. n. monas a unit, monad; N.L. fem. n. Propionicimonas propionic acidproducing monad).

Cells are Gram-positive, irregular rods. Facultatively anaerobic chemo-organotroph. Non-motile and nonspore-forming. Mesophilic. Oxidase-, catalase- and nitrate reduction-negative. Propionate is produced anaerobically from glucose. Cell-wall peptidoglycan contains meso-DAP; major cellular fatty acids are $\mathrm{C}_{13: 0}$, anteiso- $\mathrm{C}_{15: 0}$ and $\mathrm{C}_{15: 0}$. MK-9 $\left(\mathrm{H}_{4}\right)$ and MK-10 $\left(\mathrm{H}_{4}\right)$ are the major quinones. Genomic DNA G $+\mathrm{C}$ content is $68 \cdot 7 \mathrm{~mol} \%$. On the basis of $16 \mathrm{~S}$ rDNA sequences, the bacterium belongs to the class Actinobacteria. The genera Micropruina, Microlunatus and Friedmanniella are related most closely to this genus. The type species is Propionicimonas paludicola.

\section{Description of Propionicimonas paludicola sp. nov.}

Propionicimonas paludicola (pa.lu.di'co.la. L. n. palus, -udis swamp, marsh; L. suff. -cola derived from incola inhabitant, dweller; N.L. masc. n. paludicola an inhabitant of swamps).

Gram-positive, irregular, often slightly curved rods, $0 \cdot 4$ $0.5 \mu \mathrm{m}$ in diameter and $1.8-2.0 \mu \mathrm{m}$ in length and frequently arranged in irregular $\mathrm{V}$ - or crescent-shapes. Optimal growth occurs at $35^{\circ} \mathrm{C}$ and $\mathrm{pH} 6 \cdot 5$. Grows in the presence of up to $2 \cdot 0 \%(\mathrm{w} / \mathrm{v}) \mathrm{NaCl}$. Cells produce acetate, propionate, lactate, succinate and $\mathrm{CO}_{2}$ anaerobically from glucose. Growth and production of propionate are both stimulated by addition of cyanocobalamin to the medium. Cells grow on arabinose, xylose, fructose, galactose, glucose, mannose, cellobiose, maltose, sucrose, trehalose, glycerol, mannitol, pyruvate and lactate, but growth is scarce on ribose, lactose, malate, fumarate and succinate. Fucose, rhamnose, sorbose, melibiose, melezitose, raffinose, cellulose, glycogen, soluble starch, xylan, adonitol, dulcitol, erythritol, inositol, sorbitol, ethanol, methanol and propanol are not utilized. Chemotaxonomic characteristics of the species are the same as those described for the genus.

The type strain is $\mathrm{Wd}^{\mathrm{T}}\left(=\mathrm{JCM} 11933^{\mathrm{T}}=\mathrm{DSM} 15597^{\mathrm{T}}\right)$. Isolated from rice-plant residue ploughed into the soil of a Japanese rice field.

\section{ACKNOWLEDGEMENTS}

We thank the following at the National Institute of Advanced Industrial Science and Technology (AIST): Xian-Ying Meng for transmission electron microscopy, Aiko Sukegawa for her assistance with DNA base composition determination, Atsuko Iuchi for her help with cellular fatty acid analysis and Takako Kobayashi for her aid with determination of cell-wall peptidoglycan type.

\section{REFERENCES}

Akasaka, H., Izawa, T., Ueki, K. \& Ueki, A. (2003). Phylogeny of numerically abundant culturable anaerobic bacteria associated with 
degradation of rice plant residue in Japanese paddy field soil. FEMS Microbiol Ecol 43, 149-161.

Altschul, S. F., Madden, T. L., Schäffer, A. A., Zhang, J., Zhang, Z., Miller, W. \& Lipman, D. J. (1997). Gapped BLAST and PSI-BLAST: a new generation of protein database search programs. Nucleic Acids Res 25, 3389-3402.

Asakawa, S., Akagawa-Matsushita, M., Morii, H., Koga, Y. \& Hayano, K. (1995). Characterization of Methanosarcina mazeii TMA isolated from a paddy field soil. Curr Microbiol 31, 34-38.

Chin, K.-J. \& Janssen, P. H. (2002). Propionate formation by Opitutus terrae in pure culture and in mixed culture with a hydrogenotrophic methanogen and implications for carbon fluxes in anoxic rice paddy soil. Appl Environ Microbiol 68, 2089-2092.

Chin, K.-J., Rainey, F. A., Janssen, P. H. \& Conrad, R. (1998). Methanogenic degradation of polysaccharides and the characterization of polysaccharolytic clostridia from anoxic rice field soil. Syst Appl Microbiol 21, 185-200.

Chin, K.-J., Hahn, D., Hengstmann, U., Liesack, W. \& Janssen, P. H. (1999). Characterization and identification of numerically abundant culturable bacteria from the anoxic bulk soil of rice paddy microcosms. Appl Environ Microbiol 65, 5042-5049.

Chin, K.-J., Liesack, W. \& Janssen, P. H. (2001). Opitutus terrae gen. nov., sp. nov., to accommodate novel strains of the division 'Verrucomicrobia' isolated from rice paddy soil. Int J Syst Evol Microbiol 51, 1965-1968.

Cummins, C. S. \& Johnson, J. L. (1986). Genus I. Propionibacterium Orla-Jensen 1909, 337. In Bergey's Manual of Systematic Bacteriology, vol. 2, pp. 1346-1353. Edited by P. H. A. Sneath, N. S. Mair, M. E. Sharpe \& J. G. Holt. Baltimore: Williams \& Willkins.

Dolfing, J. (1988). Acetogenesis. In Biology of Anaerobic Microorganisms, pp. 417-468. Edited by A. J. B. Zehnder. New York: Wiley.

Garrity, G. M. \& Holt, J. G. (2001). The road map to the Manual. In Bergey's Manual of Systematic Bacteriology, 2nd edn, vol. 1, pp. 119-166. Edited by D. R. Boone, R. W. Castenholz \& G. M. Garrity. New York: Springer.

Glissmann, K. \& Conrad, R. (2000). Fermentation pattern of methanogenic degradation of rice straw in anoxic paddy soil. FEMS Microbiol Ecol 31, 117-126.

Großkopf, R., Stubner, S. \& Liesack, W. (1998). Novel euryarchaeotal lineages detected on rice roots and in the anoxic bulk soil of flooded rice microcosms. Appl Environ Microbiol 64, 4983-4989.

Hanada, S., Takaichi, S., Matsuura, K. \& Nakamura, K. (2002). Roseiflexus castenholzii gen. nov., sp. nov., a thermophilic, filamentous, photosynthetic bacterium that lacks chlorosomes. Int J Syst Evol Microbiol 52, 187-193.

Hattori, C., Ueki, A., Seto, T. \& Ueki, K. (2001). Seasonal variations in temperature dependence of methane production in paddy soil. Microb Environ 16, 227-233.

Hattori, C., Ueki, A., Fujii, H., Egashira, H. \& Ueki, K. (2002). Factors affecting seasonal and vertical variations in the methanogenic activity in paddy soil determined by the addition of methanogenic substrates. Soil Sci Plant Nutr 48, 315-324.

Henckel, T., Friedrich, M. \& Conrad, R. (1999). Molecular analyses of the methane-oxidizing microbial community in rice field soil by targeting the genes of the $16 \mathrm{~S}$ rRNA, particulate methane monooxygenase, and methanol dehydrogenase. Appl Environ Microbiol 65, 1980-1990.

Hengstmann, U., Chin, K.-J., Janssen, P. H. \& Liesack, W. (1999). Comparative phylogenetic assignment of environmental sequences of genes encoding $16 \mathrm{~S}$ rRNA and numerically abundant culturable bacteria from an anoxic rice paddy soil. Appl Environ Microbiol 65, 5050-5058.
Holdeman, L. V., Cato, E. P. \& Moore, W. E. C. (1977). Anaerobe Laboratory Manual, 4th edn. Blacksburg, VA: Virginia Polytechnic Institute and State University.

Hungate, R. E. (1966). The Rumen and its Microbes. New York: Academic Press.

Janssen, P. H., Schuhmann, A., Mörschel, E. \& Rainey, F. A. (1997). Novel anaerobic ultramicrobacteria belonging to the Verrucomicrobiales lineage of bacterial descent isolated by dilution culture from anoxic rice paddy soil. Appl Environ Microbiol 63, 1382-1388.

Kaku, N., Ueki, A., Fujii, H. \& Ueki, K. (2000). Methanogenic activities on rice roots and plant residue and their contribution to methanogenesis in wetland rice field soil. Soil Biol Biochem 32, 2001-2010.

Kamagata, Y. \& Mikami, E. (1991). Isolation and characterization of a novel thermophilic Methanosaeta strain. Int J Syst Bacteriol 41, 191-196.

Khalil, M. A. K. (2000). Atmospheric Methane: its Role in the Global Environment. Berlin: Springer.

Komagata, K. \& Suzuki, K. (1987). Lipids and cell-wall analysis in bacterial systematics. Methods Microbiol 19, 161-203.

Krone, U. E., Thauer, R. K. \& Hogenkamp, H. P. C. (1989). Reductive dehalogenation of chlorinated $\mathrm{C}_{1}$-hydrocarbons mediated by corrinoids. Biochemistry 28, 4908-4914.

Kushida, H. (1980). An improved embedding method using ERL 4206 and Quetol 653. J Electron Microsc 29, 193-194.

Maszenan, A. M., Seviour, R. J., Patel, B. K. C., Schumann, P., Burghardt, J., Webb, R. I., Soddell, J. A. \& Rees, G. N. (1999). Friedmanniella spumicola sp. nov. and Friedmanniella capsulata sp. nov. from activated sludge foam: Gram-positive cocci that grow in aggregates of repeating groups of cocci. Int J Syst Bacteriol 49, $1667-1680$

Nakamura, K., Hiraishi, A., Yoshimi, Y., Kawaharasaki, M., Masuda, K. \& Kamagata, Y. (1995). Microlunatus phosphovorus gen. nov., sp. nov., a new Gram-positive polyphosphateaccumulating bacterium isolated from activated sludge. Int J Syst Bacteriol 45, 17-22.

Pitcher, D. G. \& Collins, M. D. (1991). Phylogenetic analysis of some LL-diaminopimelic acid-containing coryneform bacteria from human skin: description of Propionibacterium innocuum sp. nov. FEMS Microbiol Lett 84, 295-300.

Rajagopal, B. S., Belay, N. \& Daniels, L. (1988). Isolation and characterization of methanogenic bacteria from rice paddies. FEMS Microbiol Ecol 53, 153-158.

Rosencrantz, D., Rainey, F. A. \& Janssen, P. H. (1999). Culturable populations of Sporomusa spp. and Desulfovibrio spp. in the anoxic bulk soil of flooded rice microcosms. Appl Environ Microbiol 65, 3526-3533.

Roth, J. R., Lawrence, J. G. \& Bobik, T. A. (1996). Cobalamin (coenzyme $\mathrm{B}_{12}$ ): synthesis and biological significance. Annu Rev Microbiol 50, 137-181.

Saitou, N. \& Nei, M. (1987). The neighbor-joining method: a new method for reconstructing phylogenetic trees. Mol Biol Evol 4, 406-425.

Satoh, A., Watanabe, M., Ueki, A. \& Ueki, K. (2002). Physiological properties and phylogenetic affiliations of anaerobic bacteria isolated from roots of rice plants cultivated on a paddy field. Anaerobe 8, 233-246.

Schumann, P., Prauser, H., Rainey, F. A., Stackebrandt, E. \& Hirsch, P. (1997). Friedmanniella antarctica gen. nov., sp. nov., an LL-diaminopimelic acid-containing actinomycete from Antarctic sandstone. Int J Syst Bacteriol 47, 278-283.

Seiler, W., Holzapfel-Pschorn, A., Conrad, R. \& Scharffe, D. (1984). Methane emission from rice paddies. J Atmos Chem 1, 241-268. 
Shintani, T., Liu, W.-T., Hanada, S., Kamagata, Y., Miyaoka, S., Suzuki, T. \& Nakamura, K. (2000). Micropruina glycogenica gen. nov., sp. nov., a new Gram-positive glycogen-accumulating bacterium isolated from activated sludge. Int J Syst Evol Microbiol 50, 201-207.

Strobel, H. J. (1992). Vitamin $B_{12}$-dependent propionate production by the ruminal bacterium Prevotella ruminicola 23. Appl Environ Microbiol 58, 2331-2333.

Stupperich, E., Eisinger, H.-J. \& Schurr, S. (1990). Corrinoids in anaerobic bacteria. FEMS Microbiol Rev 87, 355-360.

Takai, Y. (1970). The mechanism of methane fermentation in flooded paddy soil. Soil Sci Plant Nutr 16, 238-244.

Tamaoka, J., Katayama-Fujimura, Y. \& Kuraishi, H. (1983). Analysis of bacterial menaquinone mixtures by high performance liquid choromatography. J Appl Bacteriol 54, 31-36.

Thompson, J. D., Higgins, D. G. \& Gibson, T. J. (1994). CLUSTAL W: improving the sensitivity of progressive multiple sequence alignment through sequence weighting, position-specific gap penalties and weight matrix choice. Nucleic Acids Res 22, 4673-4680.

Ueki, A. \& Suto, T. (1979). Cellular fatty acid composition of sulfatereducing bacteria. J Gen Appl Microbiol 25, 185-196.

Ueki, A., Matsuda, K. \& Ohtsuki, C. (1986). Sulfate-reduction in the anaerobic digestion of animal waste. J Gen Appl Microbiol 32, 111-123.

Ueki, A., Nishida, S., Kumakura, M., Kaku, N., Kainuma, Y., Hattori, C., Fujii, H. \& Ueki, K. (1999). Effects of organic matter application, temperature and sunshine duration on seasonal and annual variations of methanogenic activity in wetland rice field soil. Soil Sci Plant Nutr 45, 811-823.

Ueki, A., Kainuma, Y., Fujii, H. \& Ueki, K. (2000). Seasonal variations in vertical distribution of methanogenic activity and $\mathrm{Fe}$ (II) content and relationship between them in wetland rice field soil. Soil Sci Plant Nutr 46, 401-415.

von Wintzingerode, F., Selent, B., Hegemann, W. \& Göbel, U. B. (1999). Phylogenetic analysis of an anaerobic, trichlorobenzenetransforming microbial consortium. Appl Environ Microbiol 65, 283-286.

Wassmann, R., Neue, H.-U., Lantin, R. S., Buendia, L. V. \& Rennenberg, H. (2000a). Characterization of methane emissions from rice fields in Asia. I. Comparison among field sites in five countries. Nutr Cycl Agroecosyst 58, 1-12.

Wassmann, R., Neue, H.-U., Lantin, R. S., Makarim, K., Chareonsilp, N., Buendia, L. V. \& Rennenberg, H. (2000b). Characterization of methane emissions from rice fields in Asia. II. Differences among irrigated, rainfed, and deepwater rice. $\mathrm{Nutr} \mathrm{Cycl}$ Agroecosyst 58, 13-22.

Watanabe, A., Satoh, Y. \& Kimura, M. (1995). Estimation of the increase in $\mathrm{CH}_{4}$ emission from paddy soils by rice straw application. Plant Soil 173, 225-231.

White, R. H. \& Zhou, D. (1993). Biosynthesis of the coenzymes in methanogens. In Methanogenesis: Ecology, Physiology, Biochemistry \& Genetics, pp. 409-444. Edited by J. G. Ferry. New York: Chapman \& Hall.

Wind, T., Stubner, S. \& Conrad, R. (1999). Sulfate-reducing bacteria in rice field soil and on rice roots. Syst Appl Microbiol 22, 269-279.

Yagi, K. \& Minami, K. (1990). Effect of organic matter application on methane emission from some Japanese paddy fields. Soil Sci Plant Nutr 36, 599-610.

Yokota, A., Tamura, T., Takeuchi, M., Weiss, N. \& Stackebrandt, E. (1994). Transfer of Propionibacterium innocuum Pitcher and Collins 1991 to Propioniferax gen. nov. as Propioniferax innocua comb. nov. Int J Syst Bacteriol 44, 579-582. 